Zeszyty Naukowe Szkoły Głównej Gospodarstwa Wiejskiego

Ekonomika i Organizacja Gospodarki Żywnościowej nr 120, 2017: 133-146

DOI 10.22630/EIOGZ.2017.120.44

Krystyna Świetlik

Zakład Badań Rynkowych

Instytut Ekonomiki Rolnictwa i Gospodarki Żywnościowej - Państwowy Instytut

Badawczy w Warszawie

\title{
Ewolucja i uwarunkowania popytu na usługi gastronomiczne w Polsce w latach 2000-2015
}

\section{Wstęp}

Żyjemy w dobie postindustrialnej, której cechą charakterystyczną jest dominująca rola usług w gospodarce światowej, a także w gospodarkach narodowych, zwłaszcza krajów wysoko rozwiniętych [Buera i Kaboski 2012]. Postępuje proces ,industrializacji” usług oraz serwicyzacji pozostałych sfer gospodarowania [Szukalski 2004]. Serwicyzacja, określana także mianem deindustrializacji lub tercjaryzacji gospodarki, jest uznawana za jeden z podstawowych megatrendów współczesnego świata [Skórska 2011].

O rosnącej pozycji usług we współczesnych gospodarkach decydują głównie: procesy globalizacji i integracji, wzrost zamożności społeczeństw, postęp techniczny i dyfuzja nowych technologii, wzrost znaczenia kapitału ludzkiego i jakości życia, relatywnie wysoki stopień zaspokojenia popytu na dobra żywnościowe i nieżywnościowe oraz zmiany w strukturze społeczeństw i ich otoczeniu zewnętrznym [Skórska 2013].

Rozwój usług jest procesem związanym z ewolucją trójsektorowej struktury gospodarczej [Kwiatkowski 1980]. Według twórców tej teorii postępujący rozwój gospodarczy prowadzi do zmniejszenia roli sektora I (rolnictwo), wzrostu, a następnie stabilizacji i spadku roli sektora II (przemysł i budownictwo) oraz umacniania się sektora III (usługi) w tworzeniu PKB [Bywalec 2007, Kłosiński 2011, Growiec i in. 2014, Winiecki 2014].

Od początku lat 90. XX wieku w polskiej gospodarce rozpoczął się proces zmian strukturalnych idących w kierunku jej serwicyzacji [Lichniak 2010, Szymańska 2015]. Choć w okresie tym obserwuje się z jednej strony bezpreceden- 


\section{4}

sową, szybką konwergencję gospodarczą względem krajów Europy Zachodniej [Piątkowski 2013], to równocześnie, zgodnie z tendencjami uwidaczniającymi się w grupie krajów wysoko rozwiniętych, postępuje też proces realokacji pracy i kapitału z sektora rolniczego oraz przemysłowego w stronę usług. W efekcie systematycznie maleje udział przemysłu i rolnictwa w tworzeniu PKB na korzyść sektora usług [Dąbrowska 2013a]. Potwierdzeniem tego są zmiany obserwowane w strukturze wartości dodanej oraz populacji pracujących w poszczególnych działach gospodarki [GUS 2004, 2016a].

Rośnie także znaczenie usług w sferze konsumpcji, które to zjawisko określa się mianem serwicyzacji konsumpcji [Bywalec 2003, Rudawska 2009, Dąbrowska i in. 2010, Dąbrowska 2013b]. Polega ono na zastępowaniu nabywania produktów materialnych korzystaniem z usług i znajduje odzwierciedlenie we wzroście udziału wydatków na usługi w strukturze wydatków gospodarstw domowych [Bywalec 2010].

W 2000 roku w Polsce przeciętne miesięczne wydatki na żywność i napoje bezalkoholowe w przeliczeniu na 1 osobę w gospodarstwach domowych ogółem stanowiły $30,8 \%$ całkowitych wydatków, na towary nieżywnościowe $40,2 \%$, a na usługi $21,5 \%$. W 2015 roku udział wydatków na żywność zmniejszył się do $24,0 \%$, udział wydatków na towary nieżywnościowe wyniósł $39,6 \%$, a na usługi zwiększył się do $27,8 \%{ }^{1}$. Zmiany te są potwierdzeniem zarówno prawa Engla, teorii funduszu swobodnej decyzji Katony, jak i teorii Maslowa [Zalega 2012]. Serwicyzacji konsumpcji sprzyja poprawa sytuacji ekonomicznej społeczeństwa, dążenie do osiagnięcia coraz wyższego poziomu i jakości życia oraz to, że popyt na usługi jest nieograniczony [Włodarczyk 2016].

Współczesny rynek usług charakteryzuje się coraz większą specjalizacją podmiotów oferujących usługi. Do najstarszych i najbardziej popularnych form działalności usługowej należy gastronomia definiowana jako: „wyodrębniona w społecznym podziale pracy zorganizowana działalność gospodarcza, która polega na zaspokajaniu potrzeb żywieniowych konsumentów poprzez sprzedaż gotowych potraw i napojów, stwarzanie warunków umożliwiających ich konsumpcję na miejscu sprzedaży oraz świadczenie różnorodnych usług zaspokajających potrzeby w zakresie rozrywki, odpoczynku i psychicznej regeneracji sił" [Sala 2011a]. Zmieniające się realia rynkowe i style życia ludności wpływają na intensywność korzystania z usług tej branży.

Celem prezentowanego artykułu jest rozpoznanie tendencji w rozwoju popytu na usługi gastronomiczne w Polsce w latach 2000-2015 w ujęciu makroi mikroekonomicznym, wskazanie czynników determinujących jego poziom i strukturę oraz zobrazowanie jego zróżnicowania w przekroju grup społeczno-

\footnotetext{
${ }^{1}$ Pozostała część wydatków obejmuje wydatki niekonsumpcyjne, wydatki na alkohol i tytoń, dary oraz pozostałe wydatki.
} 
-ekonomicznych ludności. Podstawę analizy stanowiły wtórne źródła empiryczne zaczerpnięte ze statystyki handlu oraz budżetów gospodarstw domowych GUS. Sięgnięto również do raportów firm badających różne sektory gospodarcze, w tym rynek gastronomiczny (m.in. CBOS, Restauratorzy Food Consulting, Sfinks Polska S.A.). Wykorzystano materiały i publikacje IERiGŻ-PIB oraz inne specjalistyczne publikacje naukowe i popularnonaukowe.

\section{Metodyka badań}

Realizacji przyjętego celu badawczego podporządkowano układ artykułu, który w warstwie metodologicznej łączy elementy rozważań teoretycznych i praktycznych. Omówienie wyników badań empirycznych poprzedza charakterystyka wybranych czynników determinujących popyt na usługi gastronomiczne. Przedmiotem prezentowanych rozważań są budżety gospodarstw domowych badane corocznie przez GUS, a w ich ramach miesięczne poziomy wydatków na gastronomię w przeliczeniu na 1 osobę, w zależności od rodzaju usług i cech społeczno-demograficznych gospodarstw domowych oraz statystyki handlu wewnętrznego obrazujące zmiany rocznej wielkości sprzedaży w cenach stałych, w zakładach gastronomicznych i placówkach handlu detalicznego. W celu skwantyfikowania zmian rzeczywistej skali wydatków (w ujęciu realnym) posłużono się zagregowanymi wskaźnikami cen detalicznych towarów i usług konsumpcyjnych dla działu: „restauracje i hotele”, o stałej i zmiennej podstawie, szacowanymi dla poszczególnych grup gospodarstw domowych. Podmiotem rozważań jest sektor gospodarstw domowych będący jednym $\mathrm{z}$ sektorów instytucjonalnych w rachunkach narodowych [GUS 2016b] oraz indywidualny konsument reprezentowany przez gospodarstwo domowe monitorowane przez GUS w badaniu budżetów gospodarstw domowych.

Zakres czasowy rozważań obejmuje lata 2000-2015. Ze względu na wprowadzone przez GUS w 2013 roku zmiany metodologiczne dane o wydatkach gospodarstw domowych na poszczególne rodzaje usług gastronomicznych w latach 2013-2015 są nieporównywalne z danymi za lata wcześniejsze; porównywalny jest tylko ogólny poziom wydatków. $Z$ tego powodu w artykule skoncentrowano się na analizie i ocenie zmian łącznych wydatków gospodarstw domowych na żywienie poza domem. Przyjęto, że rokiem bazowym do porównań będzie 2000 rok.

W analizie i ocenie materiału empirycznego zastosowano metody analizy statystycznej, ekonomicznej i porównawczej. Zgromadzone dane przedstawiono $\mathrm{w}$ formie opisowej i graficznej. 


\section{Ewolucja czynników determinujących popyt na usługi gastronomiczne}

Pod koniec XX wieku spożywanie posiłków poza domem, w zakładach gastronomicznych, nie było w Polsce zjawiskiem powszechnym. W latach 1998-1999 przeciętne miesięczne wydatki na gastronomię w przeliczeniu na 1 osobę w gospodarstwach domowych ogółem stanowiły 0,9\% całkowitych wydatków oraz 2,8\% wydatków na żywność i napoje bezalkoholowe. Obecnie Polacy dużo częściej korzystają z usług placówek gastronomicznych i wydają na nie coraz większe kwoty. Z badań wynika, że co trzeci Polak regularnie jada w restauracjach i liczba ta z roku na rok wzrasta [Restauratorzy Food Consulting 2016]. Według GUS w latach 2000-2015 wydatki gospodarstw domowych na usługi gastronomiczno-hotelarskie wzrosły ponad 5-krotnie. Wzrost zainteresowania żywieniem poza domem odzwierciedla nie tylko styl życia Polaków, ale także ich siłę nabywczą i otwartość na nowości.

Rozwój rynku usług gastronomicznych jest związany przede wszystkim ze zmianami społeczno-gospodarczymi i procesem globalizacji konsumpcji [Patrzałek 2010]. Akcesja Polski do Unii Europejskiej znacząco przyspieszyła ten proces, w tym zwłaszcza ekspansję produktów globalnych i standaryzację konsumpcji określaną jako zjawisko macdonaldyzacji. Wśród makroekonomicznych czynników determinujących zapotrzebowanie na usługi gastronomiczne podstawową rolę odgrywają dochody ludności. Wraz ze wzrostem dochodów konsumenci zakupują nie tylko więcej usług, lecz także kierują popyt na lepsze jakościowo i smakowo posiłki oraz są skłonni płacić za nie odpowiednio wyższe ceny [Sala 2000]. Istotne znaczenie w kształtowaniu popytu na usługi gastronomiczne mają czynniki demograficzne, takie jak:

- zmiana struktury demograficznej ludności,

- wydłużanie się życia, tzw. population greying, oraz wzrost liczby osób w wieku poprodukcyjnym,

- mniejsza liczba dzieci w rodzinie i postępujący proces starzenia się społeczeństwa,

- zmiana struktury gospodarstw domowych, w tym głównie wzrost udziału gospodarstw 1-2-osobowych.

Do klasycznych czynników stymulujących popyt na usługi gastronomiczne należą czynniki związane z pracą i czasem wolnym, z których najważniejsze to:

- wzrost angażowania się w pracę powodujący wydłużanie się czasu pracy i ograniczanie czasu wolnego [GUS 2017],

- zwiększenie aktywności zawodowej kobiet [PwC 2017], 
- oddalenie miejsca pracy i nauki od miejsca zamieszkania [Dąbrowska 2008, Sala 2011b],

- tempo pracy wymuszające zmianę pór jedzenia posiłków [Dąbrowska 2008, Sala 2011b],

- zmiany w sposobie gospodarowania czasem wolnym [Dąbrowska 2008, Sala 2011b],

- ogólny wzrost tempa życia [Interaktywny Instytut Badań Rynkowych 2013].

Istotnymi zmiennymi mającymi wpływ na rozwój zapotrzebowania na usługi gastronomiczne są także: poziom urbanizacji, nasilenie ruchu turystycznego oraz poziom wykształcenia ludności. Zmiany społeczno-ekonomiczne towarzyszące rozwojowi urbanizacji prowadzą do wzrostu zatrudnienia w pozarolniczych działach gospodarki oraz zmian wzorców konsumpcyjnych i stylu życia. Usługi gastronomiczne stanowią jeden z najważniejszych elementów infrastruktury turystycznej [Knowles 2001]. Poziom wykształcenia kształtuje popyt na usługi gastronomiczne dwojako: z jednej strony rozwija potrzebę, z drugiej zaś umożliwia jej zaspokojenie. $Z$ poziomem wykształcenia wiąże się poziom dochodów, otwartość na przyjmowanie produktów globalnych, zdolność do absorbcji innowacji oraz świadomość żywieniowa, która ma zasadniczy wpływ na zachowania żywieniowe.

Obszerną grupę czynników sprzyjających wzrostowi zapotrzebowania na usługi żywieniowe i zwiększających ich znaczenie społeczne tworzą czynniki kulturowe, związane ze zmianą zwyczajów żywieniowych, tradycji, nawyków, postaw, upodobań itp. Efektem zmian obyczajowości jest między innymi wzrost popularności spożywania posiłków w lokalach gastronomicznych w gronie rodziny lub znajomych, celebrowanie uroczystości rodzinnych, omawianie i finalizowanie kwestii zawodowych, organizowanie spotkań biznesowych, typu event, konferencji czy koncertów. Żywienie poza domem odzwierciedla powszechną tendencję dążenia do wygody, ułatwiania sobie życia i hedonizmu, potrzebę przynależności, wspólnego spędzania czasu i budowania relacji, jest elementem życia towarzyskiego i nowoczesnego, „zachodniego" stylu konsumpcji.

$\mathrm{Na}$ sferę popytu na usługi gastronomiczne aktywnie oddziałują również uwarunkowania podażowe związane ze stanem infrastruktury gastronomicznej i dostępnością lokali, jakością oraz nowoczesnością usług i form obsługi konsumenta. Na szczególną uwagę zasługuje rozwój placówek typu: fast food, street food, food truck, fast casual, slow food, takeaway (jedzenie „,na wynos”), food court itp. [Górska-Warsewicz i in. 2013]. Znaczącą rolę w kształtowaniu zapotrzebowania na usługi gastronomiczne należy przypisać także rozwojowi sklepów wielkopowierzchniowych i centrów handlowych oraz mediom, w tym 
przede wszystkim programom telewizyjnym kreującym zwyczaj jedzenia poza domem, zwłaszcza w restauracjach.

Analizując czynniki determinujące popyt na usługi gastronomiczne, nie można pominąc czynników działających na korzyść utrzymania tradycyjnego sposobu żywienia. Są nimi głównie: bariera finansowa, rozszerzenie dostępności i oferty rynkowej produktów w wysokim stopniu przygotowanych do spożycia i dań gotowych (tzw. żywności wygodnej), które skracają czas oraz oszczędzają wysiłek związany z przyrządzaniem posiłków w domu, rozwój produkcji i asortymentu sprzętu AGD oraz utrwalona w społeczeństwie domocentryzacja konsumpcji i uwarunkowane kulturowo przyzwyczajenia spożywania posiłków w domu [CBOS 2014, Sfinks Polska S.A. 2015, Straczuk 2016].

\section{Wyniki badań empirycznych}

Wielkość zapotrzebowania na usługi gastronomiczne można oszacować na podstawie danych GUS o wartości sprzedaży i przychodów w placówkach gastronomicznych oraz o wydatkach gospodarstw domowych. Ich analiza pokazuje, że w 2015 roku, w porównaniu z 2000 rokiem sprzedaż w placówkach gastronomicznych w cenach stałych zwiększyła się o $31,8 \%$, przy różnokierunkowych zmianach w poszczególnych latach (rys. 1). Bezwzględny jej spadek odnotowano w latach 2001-2003 i 2008-2010, zaś wydatny wzrost - w latach 2005-2007 i 2012-2015. Ograniczenie popytu na usługi gastronomiczne w pierwszych latach minionej dekady było reakcją konsumentów na słabe tempo wzrostu dochodów, utrzymujący się wysoki poziom bezrobocia i znaczący wzrost kosztów żywienia poza domem ${ }^{2}$. Przyspieszenie tempa wzrostu gospodarczego, poprawa sytuacji dochodowej ludności i pozytywne zjawiska na rynku pracy przyczyniły się do zwiększenia sprzedaży w placówkach gastronomicznych w trzech kolejnych latach (łącznie o 8,2\%). W 2008 roku doszło do odwrócenia tej tendencji i w latach 2008-2010 sprzedaż w gastronomii spadła o 6,0\%. Odnotowany w tym czasie wydatny wzrost cen żywności (o $15,9 \%$ ), alkoholu i wyrobów tytoniowych (o 22,6\%) oraz nośników energii (o 26,3\%) $)^{3}$, kosztów najmu i pozostałych kosztów funkcjonowania placówek skutkował znaczącym wzrostem cen usług gastronomicznych $^{4}$ i obniżeniem popytu, deprecjonowanym dodatkowo przez

\footnotetext{
${ }^{2}$ W latach 2001-2003 przy wzroście cen żywności i napojów bezalkoholowych w handlu detalicznym o $3,2 \%$, ceny w gastronomii zwiększyły się o $10,3 \%$.

${ }^{3}$ Wskaźniki dotyczą cen detalicznych.

${ }^{4}$ W latach 2008-2010 ceny detaliczne towarów i usług w dziale: ,,restauracje i hotele” wzrosły o 15,1\%, przy wzroście łącznych cen towarów i usług konsumpcyjnych o 10,6\%, w tym żywności i napojów bezalkoholowych o $13,4 \%$.
} 


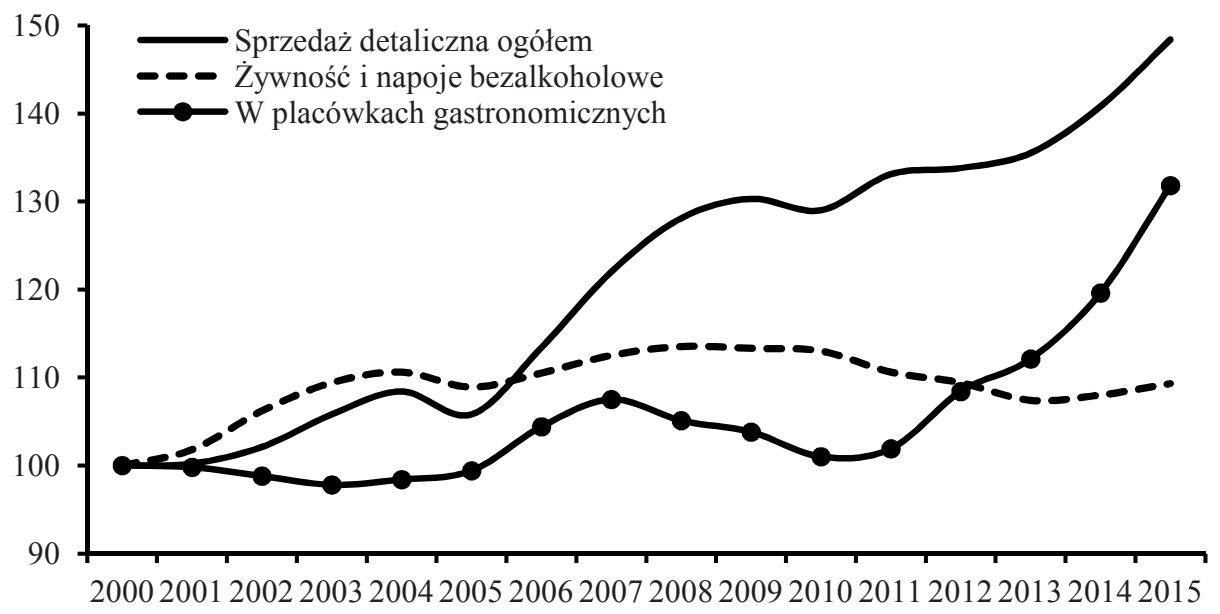

Rysunek 1

Dynamika sprzedaży detalicznej w latach 2000-2015 ( $w$ cenach stałych, 2000 r. $=100$ ) Źródło: Opracowanie i obliczenia własne na podstawie GUS [2006, 2011, 2016c].

spowolnienie dynamiki dochodów ludności. Istotnymi czynnikami hamującymi sprzedaż w gastronomii były ponadto: konieczność zmniejszenia deficytu budżetowego i związane z tym zmniejszenie wydatków na żywienie w placówkach finansowanych ze środków publicznych (szpitale, domy opieki itp.), pogorszenie sytuacji finansowo-ekonomicznej wielu przedsiębiorstw powodujące ograniczenie liczby spotkań biznesowych, jak również osłabienie ruchu turystycznego w następstwie światowego kryzysu finansowo-gospodarczego ${ }^{5}$.

W 2011 roku negatywne zjawiska w rozwoju sprzedaży gastronomicznej ustapiły pozytywnym tendencjom. W 2015 roku w porównaniu z 2010 rokiem, sprzedaż w placówkach gastronomicznych wzrosła o 30,5\%, przy wzroście sprzedaży detalicznej ogółem o 15,1\% oraz spadku sprzedaży detalicznej żywności i napojów bezalkoholowych o 3,2\% (w cenach stałych). Wzrost sprzedaży w gastronomii wiązał się głównie z odbywającymi się w Polsce mistrzostwami Europy w piłce nożnej (Euro 2012), wzmożonym napływem turystów oraz poprawą sytuacji dochodowej ludności notowaną od połowy 2013 roku. Dodatkowym czynnikiem sprzyjającym wzrostowi popytu na usługi gastronomiczne była utrzymująca się w latach 2014-2015 deflacja na rynku żywnościowym.

\footnotetext{
${ }^{5}$ Problemy natury finansowej związane z rosnącymi kosztami prowadzenia działalności gospodarczej, zaostrzenie przez banki kryteriów przyznawania kredytów i trudności z pozyskaniem kapitału doprowadziły do zahamowania ekspansji sieci gastronomicznych i redukcji liczby placówek w tym okresie. W 2011 roku w stosunku do 2007 roku liczba placówek gastronomicznych zmalała o 20,0\%, z czego w sektorze publicznym o $32,0 \%$.
} 
Interesująco przedstawiają się zmiany poziomu i struktury przychodów z działalności gastronomicznej. W latach 2000-2015, pomimo spadku liczby placówek gastronomicznych, wzrosły one: w cenach bieżących o $104,1 \%$, a w stałych o $27,2 \%$. Zadecydowało o tym głównie zwiększenie przychodów z produkcji wyrobów ciastkarskich, kulinarnych i innych wytworzonych we własnym zakresie - w cenach bieżących o $225 \%$, a w cenach stałych o $103 \%{ }^{6}$. Pozostałe przychody uległy zmniejszeniu.

W 2015 roku w porównaniu z 2000 rokiem kwoty wydatkowane przez gospodarstwa domowe na żywienie poza domem wzrosły nominalnie 5,4 razy, a realnie 3,4 razy. Największy ich wzrost odnotowano w gospodarstwach domowych rolników, a najniższy w gospodarstwach pracowników (tab.).

\section{Tabela}

Przeciętne miesięczne wydatki gospodarstw domowych na gastronomię w latach 2000 i 2015

\begin{tabular}{|c|c|c|c|}
\hline \multirow{3}{*}{ Gospodarstwa domowe } & \multicolumn{2}{|c|}{ Wydatki nominalne } & \multirow{2}{*}{$\begin{array}{c}\text { Wydatki realne }^{*} \\
2015\end{array}$} \\
\hline & 2000 & 2015 & \\
\hline & \multicolumn{2}{|c|}{ zł/osobę } & 2000 r. $=100$ \\
\hline Ogółem & 7,59 & 40,85 & 335,5 \\
\hline Pracowników & 10,06 & 43,28 & 269,1 \\
\hline na stanowiskach robotniczych & 6,56 & 28,31 & 269,9 \\
\hline na stanowiskach nierobotniczych & 16,01 & 61,61 & 240,7 \\
\hline Rolników & 1,42 & 13,46 & 597,3 \\
\hline Pracujących na własny rachunek & 13,33 & 62,95 & 299,8 \\
\hline Emerytów i rencistów & 4,68 & 30,72 & 377,2 \\
\hline emerytów & 4,84 & 31,04 & 370,1 \\
\hline rencistów & 4,44 & 29,30 & 371,4 \\
\hline Gospodarstwa domowe 1-osobowe & 22,70 & 99,69 & 273,8 \\
\hline Gospodarstwa domowe 6 i więcej osób & 2,95 & 17,42 & 368,1 \\
\hline
\end{tabular}

*Wskaźniki wydatków nominalnych skorygowane wskaźnikami cen towarów i usług w dziale: „restauracje i hotele” dla poszczególnych grup gospodarstw domowych.

Źródło: Opracowanie własne na podstawie publikowanych i niepublikowanych wyników badań budżetów gospodarstw domowych GUS oraz obliczeń własnych.

Analizując roczną dynamikę tych wydatków, można zauważyć dwa charakterystyczne zjawiska: utrzymujący się wzrost zainteresowania gospodarstw domowych żywieniem poza domem w warunkach spowolnienia gospodarczego, tj. w latach 2009-2013, oraz gwałtowne przyspieszenie jego tempa w kolejnych

\footnotetext{
${ }^{6}$ Wskaźniki realnych przychodów z produkcji gastronomicznej obliczono, korygując wskaźniki przychodów w cenach bieżących wskaźnikiem cen: „restauracje i hotele” $(160,4)$.
} 
dwóch latach (rys. 2). W 2013 roku w porównaniu z 2008 rokiem, w gospodarstwach domowych ogółem wydatki realne na gastronomię zwiększyły się o 39,7\%, a w 2015 roku w stosunku do 2013 roku o 51,6\%, podczas gdy wydatki na żywność konsumowaną w domu zaledwie $0,5 \%$. Wzrosły wydatki na gastronomię we wszystkich grupach gospodarstw domowych, w tym najbardziej w gospodarstwach emerytów i rencistów (o 73,9\%,) oraz pracowników (o 47,2\%).

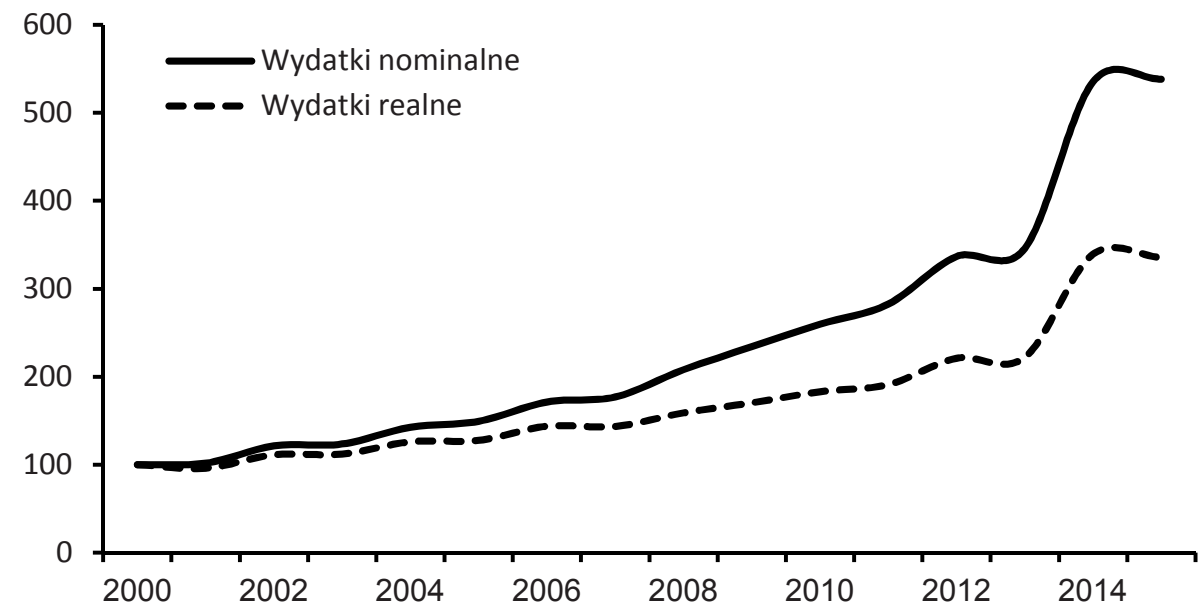

\section{Rysunek 2}

Dynamika przeciętnych miesięcznych wydatków na gastronomię w przeliczeniu na 1 osobę w gospodarstwach domowych ogółem w latach 2000-2015 (2000 r. = 100)

Źródło: Opracowanie własne na podstawie GUS [2000-2015].

Zestawienie poziomów wydatków na gastronomię (tab.) pokazuje zróżnicowanie zakresu korzystania z usług żywieniowych w zależności od typu gospodarstwa domowego i liczby osób w gospodarstwie. W 2015 roku gospodarstwami, które w największym stopniu zaspokajały potrzeby żywieniowe poza domem, były gospodarstwa utrzymujące się z pracy na rachunek własny oraz pracowników na stanowiskach nierobotniczych. Na przeciwnym biegunie znajdowały się gospodarstwa rolników, których wydatki na omawiane usługi były najmniejsze. W gospodarstwach domowych 1-osobowych wydatki na gastronomię były ponad 2-krotnie większe od przeciętnych wydatków w gospodarstwach domowych ogółem i ok. 6-krotnie większe niż w gospodarstwach liczących 6 i więcej osób ${ }^{7}$.

\footnotetext{
${ }^{7}$ Duży popyt na usługi gastronomiczne w gospodarstwach 1-osobowych jest głównie wynikiem zainteresowania tą formą żywienia młodych, żyjących w pojedynkę osób, tzw. singli. Wprawdzie nie wszystkie gospodarstwa 1-osobowe są tożsame z gospodarstwami definicyjnych singli, biorąc jednak pod uwagę małe wydatki w grupie emerytów i rencistów, z których wielu także zamieszkuje samotnie, należy sądzić, że kwoty wydawane w lokalach gastronomicznych przez gospodarstwa 1-osobowe są odzwierciedleniem preferencji wielkomiejskich singli.
} 
O wzroście znaczenia gastronomii w zaspokojeniu żywieniowych potrzeb gospodarstw domowych świadczy zwiększający się udział wydatków na gastronomię w całkowitych wydatkach gospodarstw domowych oraz w wydatkach na żywność. W 2000 roku w gospodarstwach domowych ogółem wydatki na gastronomię stanowiły $1,3 \%$ ogólnych wydatków oraz $4,1 \%$ wydatków na artykuły żywnościowe i napoje bezalkoholowe. W 2015 roku udziały te wzrosły odpowiednio do 3,7 i 15,6\%. Największy wzrost udziału wydatków na żywienie w gastronomii w wydatkach na żywność i napoje bezalkoholowe odnotowano w gospodarstwach domowych rolników (z 0,8 do 5,5\%) oraz emerytów i rencistów (z 2,2 do 9,8\%). Tak naprawdę zmiany w tych dwóch grupach gospodarstw spowodowały zmiany średniego udziału dla ogółu gospodarstw domowych. Mimo tych zmian w 2015 roku nadal największą część swoich żywnościowych wydatków na wyżywienie $\mathrm{w}$ gastronomii przeznaczały gospodarstwa domowe pracujących na własny rachunek $(23,4 \%)$ oraz pracowników na stanowiskach nierobotniczych (22,5\%), a najmniejszą - gospodarstwa rolników $(5,5 \%)$.

Zjawiska te mają kilka przyczyn. Przede wszystkim oddziałują tu czynniki ekonomiczne - poziom dochodów. Potwierdzeniem zależności korzystania z usług gastronomii od poziomu dochodów jest to, że w 2015 roku przeciętne miesięczne wydatki per capita na omawiane cele w V grupie kwintylowej w gospodarstwach domowych ogółem były 5,6 razy większe niż w I grupie kwintylowej. Udział wydatków na gastronomię w wydatkach na żywność i napoje bezalkoholowe w V grupie kwintylowej gospodarstw ogółem wyniósł 25,4\%, podczas gdy w I grupie 8,8\%. Najzamożniejsze gospodarstwa domowe pracowników na usługi gastronomiczne przeznaczyły średnio 29,7\% wydatków żywnościowych, a najuboższe $9,3 \%$. Niepoślednią rolę odgrywają tu także determinanty kulturowe. Gospodarstwa powiązane z rolnictwem w naturalny sposób, także ze względu na możliwość korzystania z samozaopatrzenia zaspokajają swoje potrzeby żywieniowe $\mathrm{w}$ domu, co jest silnie uwarunkowane tradycją. W gospodarstwach pracowników na stanowiskach nierobotniczych i gospodarstwach pracujących na własny rachunek, zarówno lepsza sytuacja materialna, system organizacji pracy, jak i styl życia są podstawowymi przesłankami częstszego korzystania z tych usług. Jest to wynikiem adaptacji do nowego systemu organizacji pracy (wydłużenie czasu pracy), a także efektem naśladownictwa i przejmowania wzorów z krajów wysoko rozwiniętych.

\section{Podsumowanie}

W ostatnich kilkunastu latach obserwuje się w Polsce wydatny wzrost zapotrzebowania na usługi gastronomiczne. Wpływ na to zjawisko mają procesy ekonomiczne, urbanizacyjne, demograficzno-społeczne i kulturowe. Polskie 
społeczeństwo aspiruje do miana społeczeństwa globalnego, a tym samym do poziomu i stylu życia właściwego dla krajów wysoko rozwiniętych, co znajduje odzwierciedlenie w coraz częstszym spożywaniu posiłków poza domem. Zmianie modelu konsumpcji, zwyczajów i preferencji żywieniowych sprzyja wzrost poziomu zamożności mieszkańców oraz podaży usług gastronomicznych.

Z danych GUS wynika, że w latach 2000-2015 przychody w placówkach gastronomicznych wzrosły o $27,2 \%$ (w cenach stałych) i były głównie generowane w obszarze produkcji gastronomicznej, co świadczy o wzroście znaczenia tego sektora w dystrybucji żywności i zaspokojeniu żywieniowych potrzeb ludności. W badanym okresie przeciętne miesięczne wydatki gospodarstw domowych na gastronomię zwiększyły się 5,4 razy. Pogorszenie koniunktury gospodarczej w latach 2009-2013 nie zahamowało popytu gospodarstw domowych na usługi gastronomiczne, a deflacja na rynku żywnościowym i znacząca poprawa sytuacji dochodowej w latach 2014-2015 doprowadziły do jego ożywienia w nienotowanej dotychczas skali (w 2015 r. w stosunku do 2013 r. wzrost realnych wydatków gospodarstw domowych na gastronomię wyniósł $52,4 \%$ ).

W 2015 roku polskie gospodarstwa domowe na żywienie poza domem przeznaczyły średnio 15,6\% wydatków na żywność, wobec 4,1\% w 2000 roku. W największej mierze z usług żywieniowych korzystały gospodarstwa domowe osób pracujących na własny rachunek i pracowników na stanowiskach nierobotniczych, a w najmniejszej - gospodarstwa domowe rolników. Różnice te w stosunku do 2000 roku uległy zmniejszeniu, ale istotne rozbieżności pozostały nadal.

Najbliższe lata powinny przynieść dalszy wzrost popytu na usługi gastronomiczne, głównie w wyniku przewidywanego wzrostu zamożności i zmian stylu życia Polaków, a także unowocześniania samego sektora gastronomicznego, pozwalającego na podniesienie jakości obsługi i dostosowanie oferty usługowej do zmieniających się potrzeb konsumentów.

\section{Literatura}

BUERA F.J., KABOSKI J.P., 2012: The Rise of the Service Economy, American Economic Review 102 (6), 2540-2569.

BYWALEC Cz., 2003: Wrost konsumpcji ustug, czyli proces serwicyzacji konsumpcji $w$ Polsce, Wiadomości Statystyczne 2, 1-8.

BYWALEC Cz., 2007: Konsumpcja w teorii i praktyce gospodarowania, Wydawnictwo Naukowe PWN, Warszawa.

BYWALEC Cz., 2010: Konsumpcja a rozwój gospodarczy i społeczny, C.H. Beck, Warszawa. CBOS, 2014: Zachowania żywieniowe Polaków, Komunikat 115, 4-7. 
DĄBROWSKA A., 2008: Rozwój rynku ustug w Polsce - uwarunkowania i perspektywy, Oficyna Wydawnicza SGH, Warszawa.

DĄBROWSKA A., 2013a: Konsument na rynku ustug w Polsce, IBRKiK, Warszawa.

DĄBROWSKA A., 2013b: Konsument na rynku ustug $w$ Polsce, IBRKiK, Warszawa.

DĄBROWSKA A., GUTKOWSKA K., JANOŚ-KRESŁO M., OZIMEK I., 2010: Serwicyzacja konsumpcji w polskich gospodarstwach domowych. Uwarunkowania i tendencje, Difin, Warszawa.

GÓRSKA-WARSEWICZ H., ŚWIĄTKOWSKA M., KRAJEWSKI K., 2013: Marketing żywności, Oficyna a Wolters Kluwer business, Warszawa.

GROWIEC J., GRADZEWICZ M., HAGEMAJER J., JANKIEWICZ Z., POPOWSKI P., PUCHALSKA K., STRZELECKI P., TYROWICZ J., 2014: Rola ustug rynkowych w procesach rozwojowych gospodarki Polski, NBP Instytut Ekonomiczny, Materiały i Studia 308.

GUS, 2004: Rynek wewnętrzny w 2003 r., Warszawa.

GUS, 2006: Rocznik Statystyczny Rzeczypospolitej Polskiej 2005, Warszawa.

GUS, 2011: Rocznik Statystyczny Rzeczypospolitej Polskiej 2010, Warszawa.

GUS, 2014: Badanie budżetu czasu ludności w 2013 r., Warszawa.

GUS, 2016a: Rachunki narodowe wedlug sektorów i podsektorów instytucjonalnych w latach 2011-2014, Warszawa.

GUS, 2016b: Rynek wewnętrzny w 2015 r., Warszawa.

GUS, 2016c: Rocznik Statystyczny Rzeczypospolitej Polskiej 2015, Warszawa.

GUS, 2017: Jakość życia w Polsce w 2015 r. Wyniki badania spójności społecznej, Warszawa.

Interaktywny Instytut Badań Rynkowych, 2013: Jak Polacy postrzegaja tempo własnego życia?, Warszawa, http://www.egospodarka.pl/98725,Tempo-zycia-Polakow-wzrasta,1,39,1.html [dostęp: 20.03.2017].

KŁOSIŃSKI K.A., 2011: Światowy rynek ustug w poczatkach XXI wieku, PWE, Warszawa.

KNOWLES T., 2001: Zarzqdzanie hotelarstwem i gastronomia, PWE, Warszawa.

KWIATKOWSKI E., 1980: Teoria trzech sektorów gospodarki, PWN, Warszawa.

LICHNIAK I. (red.), 2010: Serwicyzacja polskiej gospodarki, Oficyna Wydawnicza SGH, Warszawa.

PATRZAŁEK W. (red.), 2010: Zachowania podmiotów w warunkach globalizacji rynków, Wydawnictwo Naukowe Scholar, Warszawa.

PIĄTKOWSKI M., 2013: Poland's New Golden Age: Shifting from Europe's Periphery to its Center, The World Bank. Policy Research Working Paper 6639.

PwC, 2017: Women in Work Index 2017, Price Waterhouse Coopers, London, https://www.pwc. com/gr/en/publications/assets/women-in-work-index-2017.pdf [dostęp: 12.03.2017].

Restauratorzy Food Consulting, 2016: Przewodnik: Trendy w gastronomii 2016, Warszawa, http://www.restauratorzy.com/wp-content/uploads/2016/07/Przewodnik_trendy-w-gastronomii-2016.pdf [dostęp: 12.03.2017].

RUDAWSKA I., 2009: Ustugi w gospodarce rynkowej, PWE, Warszawa.

SALA J., 2000: Dochód a konsumpcja ustug gastronomicznych, Poradnik Restauratora 2, 6.

SALA J., 2011a: Marketing w gastronomii, PWE, Warszawa.

SALA J., 2011b: Marketing w gastronomii, PWE, Warszawa.

Sfinks Polska S.A., 2015: Strategia Sfinks Polska S.A. na lata 2015-2010, Warszawa - Piaseczno, http://www.sfinks.pl/sites/defoult/files/Strategia_Sfinks_Polska.pdf [dostęp: 20.03.2017]. 
SKÓRSKA A., 2011: Serwicyzacja polskiej gospodarki - wyzwania dla rynku pracy, Studia Ekonomiczne. Zeszyty Naukowe Wydziałowe Uniwersytetu Ekonomicznego w Katowicach 81, 93-102.

SKÓRSKA A., 2013: Uwarunkowania rozwoju sektora ustug, [w:] D. Kotlorz (red.), Serwicyzacja polskiej gospodarki - przemiany wewnatrzsektorowe, Wydawnictwo Uniwersytetu Ekonomicznego w Katowicach, Katowice, 11-53.

STRACZUK J., 2016: Smak trwania, smak zmiany. Preferencje i praktyki jedzeniowe Polaków w kontekście zmiany społecznej, Studia Socjologiczne 3, 31-51.

SZUKALSKI S.M., 2004: Serwicyzacja gospodarki i industrializacja ustug, Handel Wewnętrzny 4-5, 47-53.

SZYMAŃSKA E., 2015: Serwicyzacja gospodarki jako źródło jej transformacji, Optimum. Studia Ekonomiczne 1 (73), 97-109.

WINIECKI J., 2014: Przeksztatcenia strukturalne w procesie rozwoju gospodarczego: modyfikacje i rozszerzenia, Ruch Prawniczy, Ekonomiczny i Socjologiczny 2, 271-291.

WŁODARCZYK K., 2016: Serwicyzacja konsumpcji w polskich gospodarstwach domowych, Prace Naukowe Uniwersytetu Ekonomicznego we Wrocławiu. Ekonomia 449, 699-708.

ZALEGA T., 2012: Konsumpcja. Determinanty. Teorie. Modele, PWE, Warszawa.

\section{Abstrakt}

W artykule podjęto rozważania na temat zmian popytu na usługi gastronomiczne w Polsce w latach 2000-2015. Rozważania były prowadzone na podstawie analizy danych GUS oraz polskiej i zagranicznej literatury przedmiotu. W artykule omówiono najważniejsze czynniki decydujące o popycie na usługi żywieniowe, pokazano zmiany wielkości sprzedaży i przychodów w placówkach gastronomicznych oraz poziomu i struktury wydatków gospodarstw domowych na gastronomię. Na podstawie analizy materiału badawczego stwierdzono, że żywienie poza domem odgrywa coraz większą rolę w zaspokojeniu żywieniowych potrzeb Polaków. Świadczy o tym dynamiczny wzrost przychodów placówek gastronomicznych oraz rosnący udział wydatków na gastronomię w budżetach gospodarstw domowych. Zauważono znaczne, choć malejące, dysproporcje w wydatkach na usługi żywieniowe między poszczególnymi grupami gospodarstw domowych. Wskazano, że wpływ na to zjawisko mają głównie czynniki dochodowe oraz społeczno-kulturowe. Wyniki przeprowadzonych analiz sugerują, że zmieniające się realia rynkowe oraz style życia ludności będą kreowały dalszy wzrost popytu na usługi gastronomiczne w Polsce.

Słowa kluczowe: gastronomia, żywieniem poza domem, konsument, gospodarstwo domowe, placówki gastronomiczne, popyt na usługi gastronomiczne 


\title{
The evolution and determinants of demand for catering services in Poland 2000-2015
}

\begin{abstract}
The paper discusses the changes in catering services in Poland over the period 2000-2015. The analysis is based on the Central Statistical Office data, and the relevant Polish and foreign literature. It includes the most important factors affecting the demand for nutritional services, the changes in sales and income of catering establishments, and the structure and level of household expenditures on eating out. Based on the research, it is concluded that eating out is playing an ever-increasing role in satisfying the nutritional needs of Poles. This is evidenced by the dynamic income growth of catering establishments and the rising share of household spending on eating out in the last years. Significant but decreasing disparities in expenditures on nutritional services have been observed between various household groups. It has been shown that the main factors influencing this phenomenon are those relating to income and socio-cultural aspects. The research results suggest that changes in the market situation and life-styles of the population will create further growth in the demand for catering services in Poland.
\end{abstract}

Key words: catering, eating out, consumer, household, establishments, demand 